\title{
The Influence Of Price, Product Quality And Service Quality On Purchase Decision Of Netflix Applications
}

\author{
Waseso Segoro ${ }^{1}$, Mochamad Rifky Rifaldi ${ }^{*}$ \\ ${ }^{1,2}$ Faculty of Economics, Gunadarma University, Indonesia \\ *Corresponding Author: \\ Email: rifkyrifaldi1105@gmail.com
}

\begin{abstract}
.
This study aims to determine the effect of price, product quality and service quality on purchasing decisions partially and simultaneously or collectively. After knowing the magnitude of the influence of the three independent variables, we will find the variable that most influences the purchase decision on the Netflix application. This study uses a purposive sampling technique which is included in the type of nonprobability sampling, by distributing questionnaires to consumers of Netflix products who have bought and experienced Netflix products as many as 101 respondents. In this study using the SPSS 25 program with the analytical tools used are the Validity and Reliability Test, Multiple Linear Regression Analysis, Normality Test, Multicollinearity Test and Heteroscedasticity Test. The result of the multiple linear regression model is $Y=2.031+0.133 X 1+0.263 X 2+0.357 X 3$ and analysis shows that simultaneously there is an influence between price, product quality and service quality on purchasing decisions on the Netflix application. In addition, it was found that the $R 2$ value was 0.567 or $56.7 \%$ and the remaining $43.3 \%$ was explained or influenced by other variables not included in this study.
\end{abstract}

Keywords: Price, Product Quality, Service Quality, Purchase Decision, Netflix

\section{INTRODUCTION}

Internet use in the world has always been increasing every year, including in Indonesia. Until November 2015 internet users in Indonesia reached 88.1 million out of the total population of 255.8 million This number is predicted to continue to increase every year, reaching 133.5 million people in 2019 according to research from Statista (2016). The increase in the number of internet users has led to the emergence of many new innovations from service providers such as website-based buying and selling services (e-commerce), online news portals, elearning, social media, messaging platforms, as well as many platforms that offer streaming services such as video and also. music. As many as $85 \%$ of internet users in Indonesia access the internet via cell phones and $32 \%$ via laptops (Stenovec, T. 2015). One of the activities carried out by internet users is watching videos from their electronic devices. This is what underlies service provider companies to continue to develop and innovate in video streaming applications. Streaming itself means the process of streaming or transferring data from an internet server to the host directly(Winarno, 2013). Thus, internet users can immediately view movies or listen to songs without having to wait or upload.(Stenovec, 2015) shows an increase of nearly $30 \%$ since 2010 for people streaming video using Netflix, Youtube and Hulu.

Meanwhile, users of traditional TV and pay TV experienced a decrease of up to $10 \%$. This shows that today's digital entertainment connoisseurs have started to switch to video streaming compared to regular or pay TV services. Of the many video streaming services available, the most widely used in Indonesia today is Netflix. Netflix, Inc. is a digital streaming media service provider, headquartered in Los Gatos, California. Founded in 1997 by Reed Hasting sand Marc Randolph in Scotts Valley, California. The company's main business is a streaming subscription service, which is offered online with several film and television programs, including some created by Netflix itself.Netfilix's initial business model was DVD sales and shipping by rental. One year after being founded, Netfilix focused on renting DVDs rather than selling DVDs, so the DVD sales business was 
abandoned. In 2007, Netflix expanded its business by introducing streaming media while maintaining its DVD and Blu-ray rental services. The company is expanding its business internationally, with a streaming service available in Canada in 2010 and has continued to expand the service since then. Since January 2016, the Netflix service has operated in more than 190 countries, this service is freely available on the Internet except mainland China, Syria, the Republic of Crimea and Indonesia (some internet service providers block it due to censorship issues).

Netflix entered the content-production industry in 2012, with their debut series Lilyhammer. Netflix has expanded its production of films and television series since then on a large scale, offering "Netflix Original" content through their digital library on both television and film services. Netflix has released more than 126 "Original Series" or films in 2016, over the entire cable network or channel service.Since July 2018, Netflix has more than 130 million total subscribers internationally, including 57.38 million in the United States alone. Their efforts to produce new content, secure the rights to additional content, and differences across 190 countries have resulted in the company filing billions in long-term debt: $\$ 21.9$ billion as of September 2017, up from $\$ 16.8$ billion from the previous year, although only $\$ 6.5$ billion. of this is long term debt; the rest are long-term liabilities. Netflix headquarters is located at 121 Albright Way, Los Gatos, California, United States. They also have offices in the Netherlands, Brazil, India, Japan and South Korea.Given the large number of Netflix enthusiasts, researchers are interested in knowing what factors can affect consumer satisfaction with Netflix products. Netflix also has a fairly affordable price and commensurate with the quality of the products it has, and also the quality of service is good, this is quite important to get purchasing decisions from consumers. From the descriptions above, the researcher will discuss further in the form of scientific research entitled "The Effect of Price, Product Quality, and Product Service Quality on Purchasing Decisions on the Netflix Application".

\section{LITERATURE REVIEW}

\section{Price}

The price according to Tjiptono is an amount of money (monetary unit) and or other aspects (nonmonetary) that contain certain utilities or uses needed to get a service. Setting the price of a product is not as easy as we imagine, there are several processes that must be done in determining the price of a product.(Fandy Tjiptono, 2014).

H1: Price variable has a partially significant effect on Purchasing Decisions on Netflix products.

\section{Product quality}

According to Kotler and Armstrong, product quality is a potential strategic weapon to beat competitors. The ability of product quality to perform various functions including durability, reliability, accuracy, and ease of use.(Kotler and Armstrong, 2008).

H2: Product Quality variable has a partially significant effect on Purchasing Decisions on Netflix products.

\section{Service quality}

Service quality is an attitude based on the comparison of the expectation of consumer service quality with the company's perceived performance by consumers (Schiffman, L., \& Kanuk, 2007).

H3: Service Quality variable has a partially significant effect on Purchasing Decisions on Netflix products.

\section{Buying decision}

Purchasing decisions are the actions of consumers to want to buy a product or not. Of the various factors that influence consumers in purchasing a product or service, usually consumers always consider the quality, price and product that are already well known to the public (Kotler, 2016).

H4: Variables Price, Product Quality and Service Quality partially significant effect on Purchasing Decisions on Netflix products. 


\section{Framework}

Based on the literature review and the background that has been described, the research models and hypotheses are as shown in the figure.

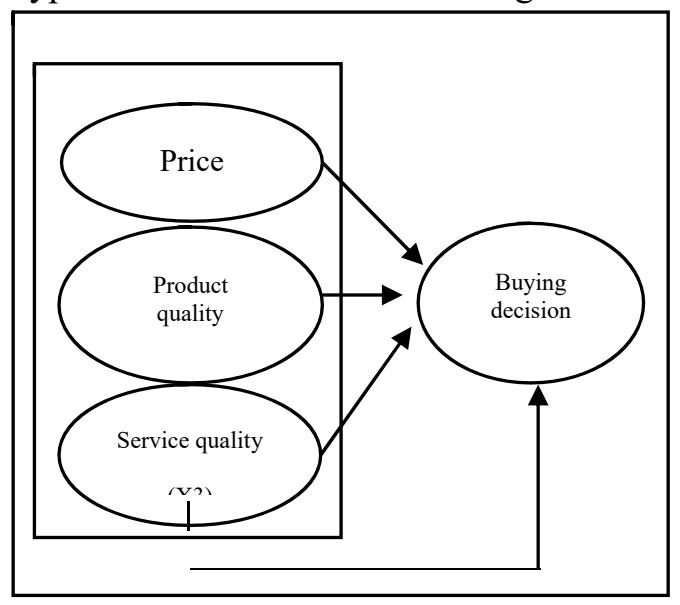

Fig 1. Framework

\section{METHODS}

In this study, the population used is Netflix product consumers in Indonesia who have bought and experienced Netflix products. The population used is large (scattered and difficult to know with certainty), so sampling is carried out in this paper. Because the population in this study. The number of samples needed in this study were 101 respondents. Sampling is needed with consideration of efficiency because it is not possible to spread the questionnaire to the entire population Sugiyono. (2011). To obtain the data studied, the sampling technique used was non-probability sampling because it was not known exactly how large the population was. This technique does not provide equal opportunities for every element or member of the population to be sampled. Taking respondents using purposive sampling technique, namely taking samples based on certain considerations and must represent the population to be studied. The data analysis technique used is validity test, reliability test, classic assumption test, multiple linear regression analysis test, determination coefficient test (R2) and hypothesis test $t$ and F.In this study, there are three independent variables, namely: (X1) Price, (X2) Product Quality, (X3) Service Quality and the dependent variable, namely (Y) Purchase Decision.

\section{RESULT AND DISCUSSION}

\section{Validity and Reliability Test}

The validity test is done by comparing the calculated $r$ value with the $r$ table for degree of freedom $(\mathrm{df})=$ $\mathrm{n}-2$, in this case $\mathrm{n}$ is the number of samples in this study, namely (n) $=101$. Then the amount of $\mathrm{df}$ can be calculated 101-2 $=99$. With $\mathrm{df}=99$ and alpha $=0.05$, you can get $\mathrm{r}$ table $=0.1956$ (by looking at $\mathrm{r}$ table at $\mathrm{df}=$ 99 with a two-way test). If the calculated $r$ value is greater than $r$ table and is positive, then the statement item or indicator is declared valid.

Table 1. Validity Test

\begin{tabular}{|l|c|c|c|c|}
\hline $\begin{array}{c}\text { V } \\
\text { variable }\end{array}$ & perly & r count & r table & Description \\
\hline $\begin{array}{l}\mathrm{H} \text { Price } \\
\text { (X1) }\end{array}$ & $\mathrm{X} 1.1$ & 0,489 & 0,196 & Valid \\
\hline
\end{tabular}




\begin{tabular}{|c|c|c|c|c|}
\hline & X1.2 & 0,657 & 0,196 & Valid \\
\hline & X1.3 & 0,648 & 0,196 & Valid \\
\hline & X1.4 & 0,674 & 0,196 & Valid \\
\hline \multirow{8}{*}{$\begin{array}{l}\text { roduct } \\
\text { Quality } \\
\text { (X2) }\end{array}$} & X2.1 & 0,687 & 0,196 & Valid \\
\hline & X2.2 & 0,629 & 0,196 & Valid \\
\hline & X2.3 & 0,671 & 0,196 & Valid \\
\hline & $\mathrm{X} 2.4$ & 0,780 & 0,196 & Valid \\
\hline & X2.5 & 0,588 & 0,196 & Valid \\
\hline & X2.6 & 0,582 & 0,196 & Valid \\
\hline & X2.7 & 0,660 & 0,196 & Valid \\
\hline & X2.8 & 0,772 & 0,196 & Valid \\
\hline \multirow{5}{*}{$\begin{array}{c}\text { uality of } \\
\text { Service } \\
\text { (X3) }\end{array}$} & X3.1 & 0,571 & 0,196 & Valid \\
\hline & X3.2 & 0,593 & 0,196 & Valid \\
\hline & X3.3 & 0,719 & 0,196 & Valid \\
\hline & X3.4 & 0,676 & 0,196 & Valid \\
\hline & X3.5 & 0,530 & 0,196 & Valid \\
\hline \multirow{5}{*}{$\begin{array}{c}\text { Purchase } \\
\text { Decision } \\
\text { (Y) }\end{array}$} & Y. 1 & 0,729 & 0,196 & Valid \\
\hline & Y. 2 & 0,770 & 0,196 & Valid \\
\hline & Y. 3 & 0,701 & 0,196 & Valid \\
\hline & Y.4 & 0,513 & 0,196 & Valid \\
\hline & Y. 5 & 0,650 & 0,196 & Valid \\
\hline
\end{tabular}

Source: Results of SPSS 25 Processing, 2020.

The reliability test in this study was tested using the Cronbach's Alpha coefficient. A variable is said to be reliable if it provides an Alpha value $(\alpha)$ of 0.6 with $(\mathrm{r}$ table $=0.1966)$. Reliability less than 0.6 is not good, while above 0.6 is good. The results of the pervariable reliability test can be seen in the table as follows:

Table 2. Reliability Test 


\begin{tabular}{|l|c|c|c|}
\hline Variable & $\begin{array}{c}\text { Cronbach's } \\
\text { Alpha }\end{array}$ & Information & $\begin{array}{c}\text { N of } \\
\text { items }\end{array}$ \\
\hline Price & 0.801 & Reliable & 4 \\
\hline $\begin{array}{l}\text { Product } \\
\text { quality }\end{array}$ & 0.892 & Reliable & 8 \\
\hline $\begin{array}{l}\text { Service } \\
\text { quality }\end{array}$ & 0.819 & Reliable & 5 \\
\hline $\begin{array}{l}\text { Buying } \\
\text { decision }\end{array}$ & 0.857 & Reliable & 5 \\
\hline
\end{tabular}

Source: Results of SPSS 25 Processing, 2020.

\section{Classic assumption test}

a. Normality test

Table 3. Normality Test

\begin{tabular}{|c|c|}
\hline \multicolumn{2}{|c|}{$\begin{array}{c}\text { One-Sample Kolmogorov-Smirnov } \\
\text { Test }\end{array}$} \\
\hline & $\begin{array}{l}\text { Unstandardized } \\
\text { Residual }\end{array}$ \\
\hline $\begin{array}{l}\text { Asymp. Sig. (2- } \\
\text { tailed) }\end{array}$ & $.064 \mathrm{c}$ \\
\hline
\end{tabular}

Based on the results of the Kolmogorov-Smirnov normality test, the independent variable has a normal distribution because the unstandardized Resiudal Asymp sig ( 2 tailed) is 0.064 which is greater than 0.05 .

b. Multiolinearity Test

Table 4. Multicollinearity Test

\begin{tabular}{|l|c|c|}
\hline \multirow{2}{*}{ Variable } & \multicolumn{2}{|c|}{ Collinearity Statistics } \\
\cline { 2 - 3 } & Tolerance & VIF \\
\hline Price & .442 & 2,263 \\
\hline $\begin{array}{l}\text { Product } \\
\text { quality }\end{array}$ & .294 & 3,405 \\
\hline $\begin{array}{l}\text { Service } \\
\text { quality }\end{array}$ & .332 & 3,012 \\
\hline
\end{tabular}

Source: Results of SPSS 25 Processing, 2020.

Based on the table above, the variables Price, Product Quality and Service Quality have a value (VIF $\leq$ 10 ) and a value (tolerance $\geq 0.10$ ). So it can be concluded that the regression model in this study does not occur multicollinearity between the independent variables.

c. Heteroscedasticity Test

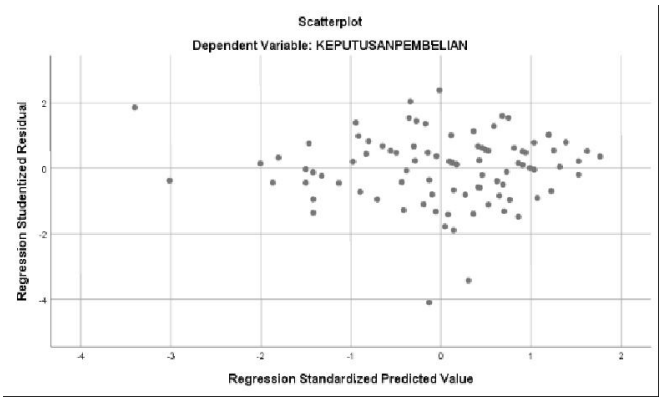

Fig 2. Heteroscedasticity Test

Source: Results of SPSS 25 Processing, 2020. 
Based on the Scatterplot graph above, it can be seen that there is no clear pattern and the points spread above and below the 0 (zero) on the $\mathrm{Y}$ axis, it is concluded that there is no heteroscedasticity in the data.

\section{Multiple Linear Regression Analysis}

Table 5. Multiple Linear Regression Analysis

\begin{tabular}{|l|c|}
\hline \multirow{2}{*}{\multicolumn{1}{|c|}{ Model }} & $\begin{array}{c}\text { Unstandardized } \\
\text { Coefficient }\end{array}$ \\
\cline { 2 - 2 } & $\mathrm{B}$ \\
\hline (Constant) & 2,031 \\
\hline Price & .133 \\
\hline Product quality & .263 \\
\hline Service quality & .357 \\
\hline
\end{tabular}

Source: Results of SPSS 25 Processing, 2020.

From the explanation above, the regression equation can be obtained as follows:

$$
\mathrm{Y}=\mathbf{2 . 0 3 1}+\mathbf{0 . 1 3 3} \mathrm{X} 1+\mathbf{0 . 2 6 3} \mathrm{X} 2+0.357 \mathrm{X3}
$$

From the above equation, it can be seen that:The price variable regression coefficient (X1) is positive indicating the tendency of the coefficient value relationship that every one-unit increase in the price variable while the other independent variables remain, there will be an increase in the purchase decision value (Y) of 0.133 units.The regression coefficient for the product quality variable (X2) is positive, indicating the tendency of the coefficient value relationship that every one-unit increase in the product quality variable while the other independent variables are constant, there will be an additional purchase decision value (Y) of 0.263 units. The regression coefficient of the service quality variable (X3) is positive indicating the tendency of the coefficient value relationship that every time there is an increase in the service quality variable by one unit while the other independent variables are constant, then there will be an additional purchase decision value (Y) of 0.357 units.

\section{4. $\quad$ T test (partial)}

Table 6. $t$ test

\begin{tabular}{|l|c|c|}
\hline \multicolumn{1}{|c|}{ Variable } & t & Significant \\
\hline Price & .967 & .336 \\
\hline $\begin{array}{l}\text { Product } \\
\text { quality }\end{array}$ & 2,954 & .004 \\
\hline $\begin{array}{l}\text { Service } \\
\text { quality }\end{array}$ & 3,008 & .003 \\
\hline
\end{tabular}

Source: Results of SPSS 25 Processing, 2020.

The results of testing the price hypothesis (X1) show the t value of 0.967 with a significant level of 0.336. This significant level is greater than 0.05 , so the hypothesis in the Hol study "Price Variables do not partially influence Purchase Decisions on Netflix products"The results of testing the Product Quality hypothesis (X3) show the $t$ value of 2.954 with a significant level of 0.004 . This significant level is less than 0.05 , so the hypothesis in the Ha2 study "Variable Product Quality has a partially significant effect on Purchasing Decisions on Netflix products"The results of testing the Service Quality hypothesis (X3) show the t value of 3.008 with a significant level of 0.003 . This significant level is less than 0.05 , so the hypothesis in the Ha3 study "Service Quality Variables have a partially significant effect on Purchasing Decisions on Netflix products"

\section{F Test (Simultaneous)}

Table 7. F test

\begin{tabular}{|l|c|c|}
\hline Variable & F & Significant \\
\hline $\begin{array}{l}\text { Buying } \\
\text { decision }\end{array}$ & 42,256 & 0.000 \\
\hline
\end{tabular}


Based on the results of the F statistical test in the table above, it shows that the F value is 42,256 with a significant probability value $<0.05$, namely 0.000 , so the decision is Ha4 accepted. So it can be concluded that "Price, Product Quality and Service Quality variables simultaneously have a significant effect on Purchasing Decisions on Netflix products".

6. Coefficient of Determination (R2)

Table 8. Coefficient of Determination (R2)

\begin{tabular}{|c|c|c|c|c|}
\hline Model & $\mathbf{R}$ & $\begin{array}{c}\mathbf{R} \\
\text { Squar } \\
\mathbf{e}\end{array}$ & $\begin{array}{c}\text { Adjusted R R } \\
\text { Square }\end{array}$ & $\begin{array}{c}\text { Std. Error } \\
\text { of the } \\
\text { Estimate }\end{array}$ \\
\hline 1 & $.753 \mathrm{a}$ & .567 & .553 & 2.46327 \\
\hline
\end{tabular}

Source: Results of SPSS 25 Processing, 2020.

Based on the table above, the adjusted $\mathrm{R} 2$ value is 0.567 . This shows that the independent variables of price, service quality and product quality are able to explain or influence the dependent variable of purchasing decisions by 0.567 or $56.7 \%$ and the remaining $43.3 \%$ is explained or influenced by other variables not included in this study.

\section{Analysis of Research Results}

In this study, the price variable has no effect on purchasing decisions, with the indicators used in this variable are price affordability, price compatibility with product quality, price competitiveness and price compatibility with benefits. In this study, respondents do not agree that the price of Netflix products is affordable, therefore this indicator is a consideration for respondents in influencing purchasing decisions on Netflix products. In other studies, the price may have influenced purchasing decisions by using different indicators.Product quality variables affect purchasing decisions by using performance indicators, features, conformance to specifications, durability, reliability, serviceability and aesthetics. This indicator has influenced respondents in making decisions to buy or subscribe to Netflix products.Service quality variables affect purchasing decisions by using indicators of reliability, responsiveness, assurance, empathy and physical evidence. This indicator has influenced respondents in making decisions to buy or subscribe to Netflix products.

\section{CONCLUSION}

Based on the results of data analysis, hypothesis testing and discussion that has been described, it is concluded that product quality and service quality affect purchasing decisions on Netflix products. Meanwhile, price does not significantly influence purchasing decisions on Netflix products. But Price, Product Quality and Service Quality simultaneously have a significant effect on Purchasing Decisions on Netflix products.

\section{REFERENCES}

[1] Kotler and Armstrong. (2008). Marketing Principles Volume I. In Erlangga.

[2] Kotler, P., \& Keller, KL (2016). Marketing Management. In Pearson Edition Limited.

[3] Stenovec, T. (2015). The Radical Transformation of TV Is Just Getting Started. Tech Insider.

[4] Sugiyono. (2011). Population, Sample, Data Normality Testing. In Statistics For Research.

[5] Tjiptono, Fandy. (2014). Service Marketing - Principles, Applications, and Research. In 